\title{
Leadership in construction. A case study with a gender perspective
}

\section{El liderazgo en la construcción. Un estudio de casos con perspectiva de género}

María Teresa Arenas-Molina (Main and Correspondant Author)

Universidad de Sevilla, Escuela Técnica Superior de Ingeniería de Edificación, Dpto. Construcciones Arquitectónicas 2, España. Avda. Reina Mercedes, s/n. 41012 Sevilla. ORCID 0000-0002-5806-3499. (+34) 687414450

marenas1@us.es; orcid.org/0000-0002-5806-3499

José María Calama Rodríguez

Universidad de Sevilla, Escuela Técnica Superior de Ingeniería de Edificación, Dpto. Construcciones Arquitectónicas 2, España.

jmcalama@us.es; orcid.org/0000-0002-0348-6785

\section{Trinidad Núñez Domínguez}

Universidad de Sevilla, Facultad de Comunicación, Dpto. de Psicología Social, España.

mtnunez@us.es; orcid.org/0000-0002-1576-7402

\author{
Manuscript Code: 715 \\ Date of Acceptance/Reception: 05.07.2016/30.11.2015 \\ DOI: $10.7764 /$ RDLC.16.1.115
}

\begin{abstract}
The existence of women to lead organizations in the construction industry, and their minimal presence in the management environment, justifies the analysis of possible barriers to their access and/or promotion. A qualitative methodology was chosen for this analysis, undertaking in-depth interviews with male and female managers in construction with the capacity to define the strategic lines of their organizations. The results offer information on the relevance of the different forms of access and promotion, and the corporate practices and culture with regard to gender related factors, affecting the recruiters' attitude to male and female candidates. The analysis of the results confirms that the male domination of the sector, the need of a guarantee taking precedence over competencies and abilities when taking up a management position, and the time management model of the organizations, are variables that prevent the promotion of women under effective equality.
\end{abstract}

Key words: Construction, leadership, glass ceiling, equal opportunities, women.

\section{Resumen}

La existencia de mujeres para liderar entidades de la industria de la construcción y su mínima presencia en los entornos directivos justifica que se analicen posibles barreras en su acceso y/o promoción. Para realizar dicho análisis se ha optado por utilizar una metodología cualitativa, realizando entrevistas en profundidad a directivos y directivas de la construcción con capacidad para definir las líneas estratégicas de sus entidades. Los resultados ofrecen datos sobre la relevancia de las diferentes modalidades de acceso y promoción, sus prácticas y la cultura empresarial respecto a factores relacionados con el género, incidiendo en la actitud de reclutadores frente a candidatos y candidatas. El análisis de los resultados permite confirmar que el dominio masculino del sector, la necesidad de un aval a la hora de acceder al puesto directivo por encima de competencias y capacidades o el modelo de gestión del tiempo de las entidades, se convierten en variables que impiden a las mujeres promocionar en igualdad efectiva.

Palabras clave: Construcción, liderazgo, techo de cristal, igualdad de oportunidades, mujer.

Introduction and Description of the Problem

The construction industry has played an important role in the economies of countries through its contributions to GDP and the jobs generated, mainly in micro and small companies. The European Construction Industry Federation (European Construction Industry Federation, 2015) reflects that role through the following figures: total construction output (€1,211 billion) accounted for 14.11 million jobs. Among the main challenges that the sector faces today, and until 2020, competitiveness of the companies is a permanent political priority, not only for growth and employment, but also to guarantee the sustainability of the sector (European Commission, 2012). In this context, Spain stands in the fifth position out of $28 \mathrm{EU}$ Member States. In this case, total construction output rose to €95 billion, with 994,000 jobs. In spite of present economic and financial difficulties, organizations such as Spain's National Construction Confederation attribute the sector with the capacity to generate infrastructure and constructions with less impact on climate change and environment, participating in the reactivation of the economy and employment.

In parallel to this economic reality of the sector, there is another social reality to consider: the spectacular growth $-49 \%$ graduated women increasing 3.9 vs. $2.6 \%$ man- in the last 10 years (European Commission, 2016). A reality that contributes a wealth of female economists, architects, engineers, lawyers and other highly qualified and competent 
professionals to the construction industry, and who can lead on an equal footing with their male peers. Nevertheless, the presence of women in the senior posts of the construction organizations is lower than men's. This is independently confirmed from the organizational charts of national professional groups and business associations, from the ECIF to the Andalusian Federation of Construction Companies.

With this background it becomes interesting to include the gender perspective, because it is the men and women that comprise it who directly affect the numbers (Instituto de la Mujer, 2008). Thoroughly analyzing what it is to be a man or woman means seeing the world from a different viewpoint. Complementarity of abilities, views, values, types of leadership, relationships and actions, could be the key to change at all levels: social, labor and political (FernándezPalacín, López-Fernández, Maeztu-Herrera \& Martín-Prius, 2010).

Theoretical Background

In relation to this under-representation of women in the upper echelons, the metaphor glass ceiling is emphasized. This was published for the first time in 1986 by the American newspaper The Wall Street Journal, alluding to the invisible barriers that prevent women from reaching executive positions. Its essence continues unchanged today and affects women with more than enough personal and professional capacity to lead (Núñez Domínguez \& Estebaranz, 2014). Walls, floors, mechanisms and barriers of procedures, structures, relationships of power, beliefs, customs, etc., are behind this, and other expressions. Thus, the glass maze refers to the obstacles that appear simultaneously and from very different angles in the ascent of women to high positions (Barberá et al., 2011; Eagly \& Carli, 2007). The metaphor glass wall denounces the limited capacity available to women to move into line positions through being systematically encapsulated in staff positions. Glass frontiers alludes to the difficulties introduced in the professional aspirations of women by the phenomenon of globalization and the offshoring of jobs (Burin, 2008). The fact that these 'glass structures' have no visible social devices or codes that impose such limitation, confers their main characteristic: imperceptibility (Burin \& Dio Bleichmar, 1996), a circumstance that complicates their elimination.

Studies on the causes that maintain the glass ceiling identify: barriers of governmental responsibility, through the lack of monitoring and forcefulness in the application of the law; organizational barriers, which affect selection practices and promotion to management positions; and barriers that operate outside the control of the companies, related to educational opportunities and those originated by conscious or unconscious gender stereotypes. Responsibilities associated with the reproductive role, traditionally attributed to and assumed by women for the maintenance of family life, occupy a prominent position. Martínez et al. (2011), in their study on working careers of women who occupy highly qualified posts, affirm that the professional careers of both sexes is characterized by stability, although there are slight differences in favour of men. In the specific analysis of women aged between 35 and 44 years, the study recognizes that their careers are more unstable and discontinuous when compared with those of their male companions, or with those of other women.

In the strategies for dismantling the identified barriers, Estebaranz et al. (2004) focused on Andalusian women who have opened paths from their management positions in companies or institutions. They concluded that the achievement of the highest professional category occurs when family responsibilities do not yet exist, delaying or declining motherhood. Another strategy consists of mitigating the situation of the double day, through family and/or external help, without forgetting the effort that these women must invest in maximizing the planning and organization of their homes. Among the strategies that are also within women's scope for manoeuvre: increasing their visibility in the working environment, principally before those who can help them in their professional careers; learning to develop and handle the unwritten rules that govern the management surroundings and to become incorporated into the informal networks of the real power (Barberá et al., 2000).

\section{Construction Industry Background}

A feminization index of 9.07 represents a strong horizontal segregation and reflects the reality of a sector in which the aptitudes and attitudes associated with the man continue to be prioritized, thereby undervaluing the potential of the woman in this labor market (Infante-Perea et al., 2012). The qualitative study of Andalusian women in the construction sector (Instituto Andaluz de la Mujer, 2003), recognizes two spaces with different values: the fieldwork and the office. Whilst the first is undertaken outside, it is visible and contributes social recognition to the people who work there (mainly men), the second, takes place inside and is invisible, it is over-represented by women and lacks social recognition. 
The characteristics of the construction industry also have an influence on the greater or lesser presence of women in management positions. Large companies display a greater degree of feminization with respect to small and medium companies (Martínez et al., 2011). Torres Martos \& Román-Onsalo (2011) show that almost $90 \%$ of the companies with less than 250 workers, do not have the obligation to produce and apply equality plans under Statutory Law 3/2007, on the Effective Equality of Women and Men. Also, and against the regulatory recommendations, there is no specification of equality measures in the provincial collective agreements (Román-Onsalo et al., 2009).

Agudo Arroyo \& Sánchez de Madariaga (2011) refer to a male model of the architecture profession that limits the professional development of female architects, and which can be extrapolated to women who practice in other areas of construction. They describe a situation in which colleagues, companions, constructors and clients continue to be unaccustomed to the presence of women in the sector, in spite of their greater numbers. The distrust of women's management qualities forces them to work twice as hard as their male counterparts in order that equal value is placed on those capacities that a priori are implicit in the men, for example: authority or competence in the supervision of activities (Román-Onsalo et al., 2013). In view of the fact that there are numerous, qualified women who could lead organizations in the construction industry, coupled with their scarce presence in the management environment, the set objective is: to identify barriers, if they exist, to women's access and/or promotion.

Methodology

Qualitative methodology, from a mainly phenomenological theoretical perspective, was chosen for this research. Work was carried out on the basis that the reality that matters, is that which people perceive as important (Taylor \& Bogdan, 1987), and that knowledge of those perceptions can be achieved through the discourse of the people who are in contact with the construction industry. The in-depth interview was used, because, as Valles (1997:185) recognizes: "it should expose the emotional implications and elicit value-laden responses from the people under study; it should obtain the relevant personal context, the idiosyncratic associations, the beliefs and the ideas".

Interviews have been performed at work places, lasting for more than one hour with open questions: what motivation led you to the current position?, how did you reach it?, did you compete with others candidates?, what are the considerations that account for Constructions Companies to assign a manager position?, ¿what if the candidate is a woman?
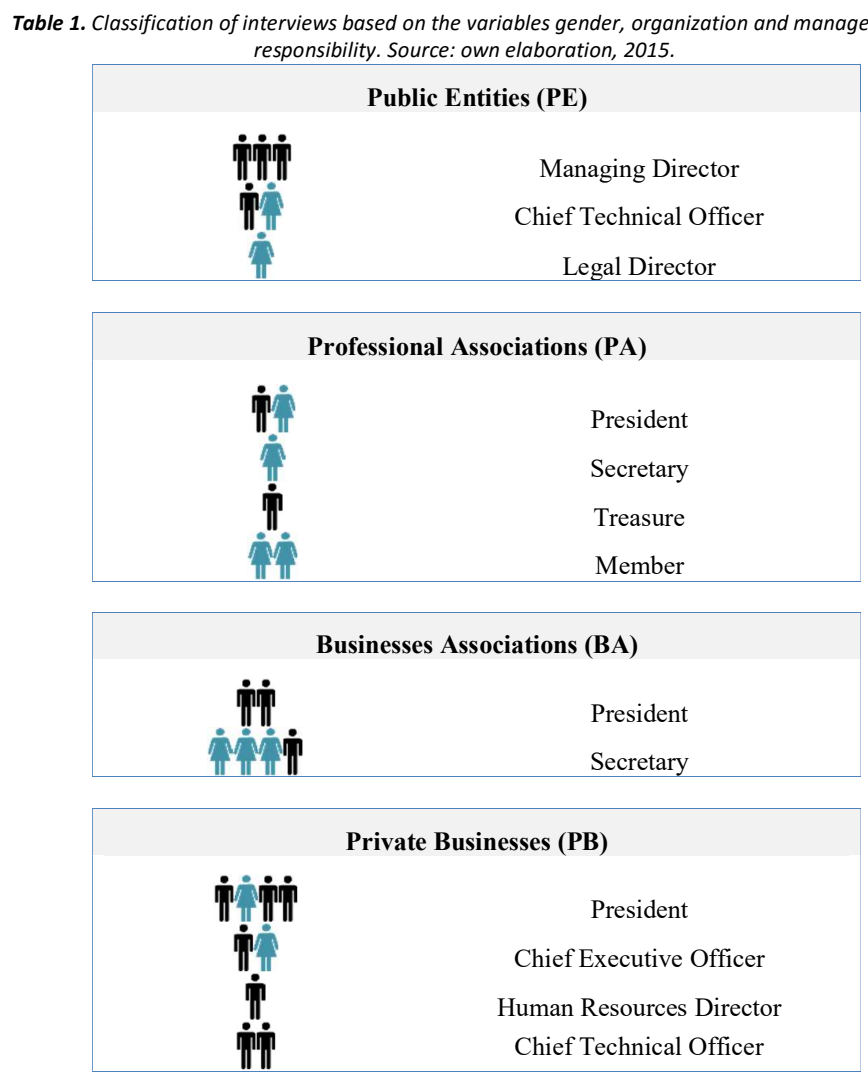
The definition of the target population was one of the more complex tasks due to the breadth of the study field. An open sampling design was chosen, oriented based on the saturation criterion established by the redundancy of the data, tracking the difference of cases and careers. The structure of this sample deals with three variables: gender, level of responsibility and type of organization. Thus, the gender variable takes in women and men, taking into account the male hegemony of the sector. The level of responsibility tracks the contributions of people with decision-making capacity and influence in the organizational strategies because those who control the discourse can indirectly control the minds of people; and given that the actions of the people are controlled by their minds (knowledge, attitudes, ideologies, standards, values), the mind control also implies the indirect control of the action (Van Dijk, 2011). Finally, the type of organization allows the analysis of the professional experiences of those people who undertake their role in organizations with diverse idiosyncrasies and objectives. Twenty-seven interviews were held with women and men who comprise the senior management bodies in: public entities, professional and business associations or SMEs with national and international reach, as shown in Table 1.

The qualitative analysis was practical, systematic and verifiable. The software chosen was Hyper Research 3.7.0, facilitating the organization, storage and analysis of coded material. Once the interview material was transcribed, it was categorized to allow text fragments to be classified by topic. For the definitive categorization (Table 2) a Delphi Study was conducted that needed the collaboration of three experts in gender and business studies. The main output was to define and validate the codes.

The final idea was to prepare a "measuring rule", a correction template for the interviews, which would allow data to be collected, about frequencies, percentages and comparisons among them, on different aspects of the public and private life of 16 male managers and 11 female managers who occupied decision-making positions in construction organizations in Andalusia.

\begin{tabular}{cl} 
Table 2. Category Access and Promotion (A). Source: own elaboration, 2015. \\
\hline Access-Tutelary \\
ATm & Men \\
ATw & Women \\
Access by & Competencies \\
ACt & University Training \\
ACm & Merit \\
ACe & Experience \\
Access. Other Factors \\
AO & Access: Occasional \\
ATf & Time Factor \\
AM & Mobility \\
Gender Factors \\
AGg & The problems associated with the \\
& reproductive role of women are of concern \\
AGe & to the organization \\
AGr & Greater level of demands on women \\
AGo & The women reject the promotion \\
AGb & Other prejudices \\
\hline
\end{tabular}

The qualitative results are shown with fragments of the interviews, preceded by an alphanumeric code (00-M/WORGANISATION). This coding thereby identified the order number of the interview, whether it was with a man (M) or a woman (W) and the type of organization in which they exerted their role: public entity (PE), professional association (PA), business association (BA) or private business (PB). The quantitative results, summarized in Table 3 and 4, were obtained from the count of references to the codes of Table 2, and reveal the priorities of male and female managers. In addition, the percentage participation of interviewees is shown for each of the subcategories and codes. 
Table 3. Priorities of male managers. Source: own elaboration, 2015.

\begin{tabular}{|c|c|c|c|}
\hline Men & & Code & $\%$ \\
\hline 1 & $\mathrm{ACt}$ & Access by training & 14.46 \\
\hline 2 & AGg & Barriers by reproductive role & 13.86 \\
\hline 3 & AT & Access - Tutelary & 12.65 \\
\hline 4 & AGo & Stereotypes and prejudices & 10.24 \\
\hline 5 & $\mathrm{ACe}$ & Access by experience & 9.04 \\
\hline \multirow[t]{2}{*}{6} & ATf & Access by time factor & 7.83 \\
\hline & $A G r$ & Female rejection of promotion & \\
\hline 7 & $\mathrm{ACm}$ & Access by merit & 7.23 \\
\hline 8 & AGe & Barriers by unequal demands & 6.63 \\
\hline 9 & $A G b$ & No barriers to access & 4.22 \\
\hline 10 & $\mathrm{AO}$ & Access: Occasional & 3.61 \\
\hline 11 & AM & Access by mobility & 2.41 \\
\hline
\end{tabular}

Table 4. Priorities of female managers. Source: own elaboration, 2015.

\begin{tabular}{cllc}
\hline Women & & \multicolumn{1}{c}{ Code } & $\%$ \\
\hline 1 & AT & Access-Tutelary & 18.98 \\
2 & AGe & Barriers by unequal demands & 17.52 \\
3 & AGg & Barriers by reproductive role & 10.95 \\
4 & ACm & Access by merit & 10.22 \\
& AGr & Female rejection of promotion & \\
5 & AGb & No barriers to access & 8.76 \\
6 & ACt & Access by training & 8.03 \\
& AGo & Stereotypes and prejudices & \\
7 & ACe & Access by experience & 2.19 \\
& AO & Access: Occasional & \\
& ATf & Access by time factor & 0.73 \\
\hline
\end{tabular}

\section{Personal data}

On Table 5, personal data of the interviewees are shown.

Table 5. Personal data. Source: own elaboration, 2015.

\begin{tabular}{lcccc}
\multicolumn{5}{c}{ Table 5. Personal data. Source: own elaboration, 2015.} \\
\hline Age (years) & \multicolumn{3}{c}{ Range } \\
\hline & 51 & 42 & 61 \\
& 42 & 36 & 51 \\
Family status & & \\
\hline
\end{tabular}

Family status

\begin{tabular}{cccc} 
& Married (\%) & Divorced (\%) & Single (\%) \\
\cline { 2 - 4 } & 100 & - & - \\
& 72.73 & 9.09 & 18.18 \\
& $\begin{array}{c}\text { No children } \\
(\%)\end{array}$ & $1-2$ children & 3 or more children \\
& 6.25 & $(\%)$ & $(\%)$ \\
\hline & 27.27 & 93.75 & 56.25 \\
& & 72.73 & 27.27
\end{tabular}

\section{Tutelary access}

The people interviewed spoke, mainly, of access/promotion that is guaranteed by people from the management structure itself or by people linked to it. In all the cases, reference was made to male tutelage (ATm). Only one manager 
in a public entity referred to the intervention of a woman (ATw). In addition, it was verified that this mode of access extends throughout all types of organizations, and that it constitutes the main priority in the case of female managers (Table 6).

\begin{tabular}{cccc}
\multicolumn{4}{c}{ Table 6. Tutelary Access. Source: own elaboration, 2015.} \\
\hline & Priority & Frequency (\%) & Referred to (\% \\
\cline { 2 - 4 } & 3 & 12.65 & 75.00 \\
1 & 18.98 & 81.82 \\
\hline
\end{tabular}

04WPA: "Through the office I know people, quantity surveyors who were in management [...] I caught their attention. They invited me to participate in the governing bodies of the Professional Association". 06WPE: "These outstanding positions are those in which the person who forms the team must have confidence in you. Perhaps you deserve a lot, but if you do not have rapport with the head of that team, they are not going to choose you".

\section{Access by competencies}

Forty-eight percent of the cases recognized that their competencies have influenced their professional career. Thirtyone percent of the male, and $9 \%$ of the female, managers considered that their academic training was important when gaining, or being promoted to, the management position (ACt). Also, 38\% of male, and 36\% of female, managers attributed it to the obtained achievements and their $\mathrm{CV}(\mathrm{ACm})$. Most references to training and merit, were concentrated in the public entities and business associations. Finally, $25 \%$ of the male managers with functions in the private sphere of the sector stated that their management promotion was due, partly, to previous professional experience (ACe).

09MBA: "They said: you come from outside, you have a law degree, you have these references from some companies which this firm advises, you are on the shortlist and you have made a good impression on us".

02MPB: "Well, for me, apart from seniority, I had practically touched on everything and passed through accounting and invoicing as, I don't know, it wasn't the thing to talk about exams or anything".

When knowledge of their organizations were added to the previous results, it was observed that $70 \%$ of the interviewed managers identified the possession of a university degree was mandatory. Similarly, $48 \%$ and $33 \%$ spoke of the importance of the CV and previous professional experience at the time of promotion, respectively (Table 7).

23WPB (exclusively through tutelary access): “A university degree would always be requested [...] it gives another, broader point of view, of vision, to know other things. It is not only what you learn in the specific subjects of the degree, but also about relating to other people, working in a team, assuming a series of roles determined in those teams, etc.".

\begin{tabular}{|c|c|c|c|}
\hline & Priority & Frequency (\%) & Referred to (\%) \\
\hline \multicolumn{4}{|c|}{ (ACt) University Training } \\
\hline & 1 & 14.46 & 75.00 \\
\hline & 6 & 8.03 & 63.64 \\
\hline \multicolumn{4}{|c|}{$(\mathrm{ACm})$ Merit/CV } \\
\hline & 7 & 7.23 & 43.75 \\
\hline & 4 & 10.22 & 54.55 \\
\hline \multicolumn{4}{|c|}{ (ACe) Previous Experience } \\
\hline 舟 & 5 & 9.04 & 43.75 \\
\hline & 7 & 2.19 & 18.18 \\
\hline
\end{tabular}

\section{Access. Other factors}

Twenty-five percent of the male, and $18 \%$ of the female, managers interviewed affirm that opportunity and chance (AO) have marked their management careers. The references to this mode are located, mainly, in the private businesses and 
their associations. 07MPR: "It was when a person in the company suggested that we leave to start a construction company together. [...] that gave me the push to start the company".

Exclusive dedication to the organization (ATf) is recognized by 7\% of the people interviewed (all of them men), having an influence on their promotion to the management position. However, $50 \%$ of male, and $18 \%$ of female, managers spoke of the time factor as an important requirement for access or promotion (Table 8 ). These references took place in the private sphere of the sector.

\begin{tabular}{ccccc}
\multicolumn{5}{c}{ Table 8. Access by time. Source: own elaboration, 2015.} \\
\hline Priority & PE (\%) & PA & BA (\%) & PB (\%) \\
\hline 6 & 50 & - & 33.33 & 71.43 \\
7 & -1 & - & 66.67 & - \\
\hline
\end{tabular}

03WPA: "I think that time, and the desire to dedicate part of your life to the company, are more important than the training that you have. So, that's the only wall that we have".

13MPB: "The access of women to management posts is very difficult. The dedication in my company, perhaps without being written... In the subconscious mind perhaps yes".

10WBA: "Yes, yes. The companies give it a lot of importance, more than they should I think. I believe that it should be more about productivity than time. [...] a woman has difficulties promoting herself like a man because she cannot attend events, because she cannot be in the bar all day making deals".

Finally, the availability to operate in different geographic locations (AM) did not figure in any of the careers of the people interviewed. However, $18 \%$ of the male, and $9 \%$ of the female, managers identify it as an important factor. The organization variable was referred to by managers from private businesses and their associations.

26MBA: (There is only one woman on the Board of Directors) "[...] I believe that mobility is the key, and that it affects both intermediate and senior positions".

\section{Gender factors}

The interest of the organizations in the existence of family duties (children) (AGg) is shown in a lower number of cases. Thus, $18 \%$ of the female managers interviewed had been consulted on the matter. However, allusions to this circumstance were present in $70 \%$ of responses, and occupied a main position among their concerns, independently of the type of organization in which they carried out their work (Table 9). It was mainly perceived as an obstacle in the management careers of women, although $13 \%$ of the male managers interviewed did not see motherhood as being prejudicial for the professional development of women. Any references by the consulted women on this matter were not recorded.

Table 9. Barriers of the reproductive role. Source: own elaboration, 2015.

\begin{tabular}{cccc}
\hline & Priority & Frequency (\%) & Referred to (\%) \\
\hline 2 & 13.86 & 56.25 \\
& 3 & 10.95 & 72.73 \\
\hline
\end{tabular}

17MPE: "Yes, family responsibilities are an impediment [...]. The fear that many companies have is: I'll give you a responsibility or put you in a position where, in a certain time, I cannot complete a long-term project due to another set of circumstances".

04WPA: "The age of a woman, the subjects of marriage, of having children and other topics carry a lot of weight, a lot".

27WPB: “... to me the profession has cost me by not being a mother, for example". 
The stereotypes and prejudices handled by the top leadership of the organizations (AGo) have played an important role in the selection processes of $18 \%$ of the female managers interviewed, all of them linked to business associations. In addition, $63 \%$ of the people interviewed identified, and/or denounced, stereotypes and prejudices about the management capacities of women, mainly on the private sector (Table 10).

03WBA: "I have to negotiate with the unions for a collective agreement that affects a very high number of workers. [...] those negotiations with the unions seemed to have been too strong to have been undertaken by a woman".

19MPB: "The environment in which one moves, the idiosyncrasy of a type of work, how the people are... All that, I think, goes more against the grain of women".

Regarding objectivity in assessment for management positions, 55\% of the female managers stated that, because of being a woman, more has been demanded of them than their male colleagues, or they have had to do more to show their worth (AGe). Thirteen percent of the male, and $91 \%$ of the female, managers consulted, recognized that a greater level of competence is demanded for women with respect to men (Table 10). On the other hand, $31 \%$ of the male, and $9 \%$ of the female, managers did not find this discrimination.

04WPA: "Leadership, work capacity, effort. In the case of being a woman you still have to demonstrate it more because you have to assert yourself more with those same characteristics [...]. For a woman to make it, they must be very competent, and stupid men make it every day. A stupid woman does not make it".

\begin{tabular}{|c|c|c|c|c|}
\hline Priority & $\mathrm{PE}(\%)$ & PA (\%) & $\mathrm{BA}(\%)$ & PB (\%) \\
\hline \multicolumn{5}{|c|}{ Stereotypes/Prejudices } \\
\hline 4 & 25 & 100 & 33.33 & 100 \\
\hline 6 & 50 & 75 & 66.67 & - \\
\hline \multicolumn{5}{|l|}{ Unequal Demands } \\
\hline 8 & - & - & 33.33 & 14.30 \\
\hline 2 & 100 & 75 & 100 & 100 \\
\hline
\end{tabular}

11MBA: "Positions of that responsibility are going to demand the same of a woman as of a man. What the business owner wants is for the company to succeed".

The reproductive role was indicated by $27 \%$ of the women as the reason for having rejected a management position in their professional career ( $\mathrm{AGr}$ ). It was verified that $50 \%$ of the male, and $66 \%$ of the female, managers consulted, thought that women exclude themselves when the possibility arises for an executive position. These statements were present in all the organizations.

21MPE: “... the conclusion I always draw on the subject is that the woman has a greater capacity of responsibility for the family, and makes the decision to prefer work-life balance to a professional challenge that detracts from that balance".

Forty-five percent of the female managers interviewed have not perceived the existence of specific barriers, nor insurmountable obstacles, through the fact of being women (AGb). In the same sense, $31 \%$ of the male managers shared that perception (Table 11).

\begin{tabular}{cccccc}
\multicolumn{6}{c}{ Table 11. Other gender factors. Source: own elaboration, 2015.} \\
\hline Priority & PE (\%) & PA (\%) & BA (\%) & PB (\%) \\
\hline No Barriers to Access & & & & \\
& 9 & - & 50 & 33.33 & 42.86 \\
& 5 & 50 & 25 & 66.67 & 50 \\
\hline
\end{tabular}

15WPE: "I have never felt ignored or prejudiced against because of my being a woman".

02MPB: (There is no woman on his Board or in departmental management). "We do not have any discrimination here against any type of woman". 
Results show that the informal networks assume a leading role in the usual selection practices when matching supply and demand in the workplace (Simpson, 2000). The greater number of references contributed by female managers supports that the possession of contacts is more important than match in the case of women. It was also observed that they did not discriminate between types of organizations. Thus, meritocracy of civil servants, which guarantees equality of opportunities between men and women regarding access and promotion, disappears when talking about high level management responsibilities.

The main quality of tutelary access is that it is an eminently male endorsement. Statements along the line of biological theories, shielded by the late access of women to university training, or the greater presence of men in the sector, could explain a priori this circumstance. However, the fact should be appreciated that it is a self-induced phenomenon caused by the influence exerted by dominant groups to maintain the status quo (Osca \& López-Sáez, 1994). In such a case, the recommendations of the Unified Good Governance Code of Listed Companies warn that this phenomenon will not be corrected if measures are not adopted to favor diversity in organizations. A context that is not helped by the reluctance shown by female managers to empower other women (Arenas-Molina, 2014).

The commitment of male and female managers of the public entities and business associations, to be more sensitive to objective criteria such as university training and the fit of the CV to the vacant position, suggests a trend towards a more qualified sector. However, although both modalities coexist and are not exclusive, the statements about tutelary access of the interviewees relegate access by competencies to the background.

In light of the scarce experiences narrated, the influence of the commitment and complete schedule availability to the organization was not openly revealed as a decisive factor for access or promotion. Nevertheless, the qualitative results point in another direction. The concentration of statements in private businesses and their associations agrees with the time dedication of the highest positions are generally designed within a male working environment (Navarro-Astor et al., 2016), and include schedules that are not usually available for women with offspring, for example, evening or night work (Burin \& Dio Bleichmar, 1996). In this sense it is especially interesting that it was basically men who assessed this subcategory, because they identified it as an obstacle in the management careers of women, constituting "invisible" barriers that become explicit if they are examined carefully (Núñez Domínguez \& Estebaranz, 2014). The crux of the issue is found in the discourse of the women, uncomfortable with this situation and hoping for a change of model.

Completing the category of access and promotion practices, are the set of aspects that condition, because of gender, the professional careers of female managers in the construction sector. It is difficult to abstract from a social reality in which one of the main stereotypes of womanhood is her portrayal in a maternal role that extols her part as protector of her family and her efficiency in the field of domestic responsibilities. Personal study of the cases, shows how most of the male managers are emotionally attached to a woman who takes care of their offspring and who constitute the main support in his professional and management career, recalling the expression: behind every great man there is always a great woman.

The belief that women prioritize their family over their work, goes beyond their experiences. It is installed in the ideology of male and female managers, causing distrust with respect to the "total commitment" of women. On the contrary, there are those statements from female managers who reject the attitude of companies and human resources managers, and vindicate the importance of co-responsibility in the couple's partnership. The absence of references to this code highlights that the interviewees were people without children and, therefore, not obstructed by this circumstance, or were male or female managers in organizations with a results oriented management model, as opposed to one demanding sole and exclusive dedication.

A "constructed" image of women also exists in the realm of associations and private businesses. It is an image loaded with prejudices and stereotypes which spreads the belief that women are more docile and not "hard" enough to undertake the lead in important negotiations (Schein, 1973). The analysis of the interviewees' responses identified opposite positions between male and female managers. The first act as if it were an echo transmitting these harmful messages for women, consciously or not, thereby justifying and causing the continuity of the male power model of the sector. Nevertheless, their female counterparts, with some exceptions, denounced the existence of the image and, sometimes, proposed actions to contribute to demolishing that image which hinders their promotion to management positions.

A third conditioner through gender, is that regarding unequal criteria of assessment and demands. A common denominator in the women's statements, as opposed to the few references contributed by the men, was, most have not found it easy to arrive at their present managerial responsibility. They showed evidence of it in allusions where they 
spoke with pride about their achievements and the effort invested to achieve success. Together with a very small number of businessmen, the female managers identified this factor as an obstacle in their professional careers. The lack of references, and the non-recognition of this inequality by male executives, denotes the indifference towards a question which, in some way, benefits them professionally. The combination of prejudices and unequal assessment of competencies in the selection practices also perpetuate the cement ceiling. This conditioner generates insecurities and conformist attitudes towards their working career (Núñez Domínguez \& Estebaranz, 2014). To overcome it, according to the experiences of the interviewees, requires motivation, ambition, organization, capacity for work and shared responsibility with the partner.

The results show the complexity, subtlety and invisibility of these barriers. It was verified that this circumstance makes women a subjective construct which can be overcome individually, with will, doing well, and with the force of one's own desire (Burin, 2008). Thus, their personal struggle justifies why these female managers do not recognize the existence of a "glass ceiling" in their professional careers.

- The glass ceiling in the Andalusian construction sector is a current reality, and is present in all the types of organizations analyzed. However, it is in private businesses, and their associations, where difficulties in access and promotion to managerial responsibility because of gender are perceived to a greater degree.

- The glass ceiling is sustained in selection practices that relegate the competencies of male and female candidates to the background. The access/promotion takes place thanks to the endorsement of a person from the managerial environment of the organization, or with influence over it. It was noticed that the need of a tutor or mentor is greater in the case of female managers.

- The scarce presence of women with capacity to exert the tutelage is concomitant with the male control of these practices of access/promotion to managerial responsibility.

- Construction is perceived as something masculine and hostile for women, as are leadership positions. In particular, prejudices and stereotypes inherited from the social structure in general, and the family structure of their mentors, are identified. The reproductive role of women is perceived as one of the main obstacles to their managerial career.

- The subjectivity of the people responsible for the assessment, impacts directly on the arbitrariness of the deliberations applied to male and female candidates. The women interviewed identified discriminatory assessments in the selection processes with respect to their male counterparts.

- A management model based on the amount of time dedicated to the organization also perpetuates the glass ceiling. This model ignores the social needs of the families, hindering access/promotion for women with children. In extreme cases, it conditions the family structure of those women who delay or decline motherhood.

- The breaking of the glass ceiling occurs unconsciously through the sacrifice, effort and perseverance of the women who seek managerial responsibility.

Conclusions from this study are obtained from a particular region in Spain (Southern Spain) and hence, some differences may arise if this analysis is compared to other from different areas.

References

Agudo Arroyo, Y., \& Sánchez de Madariaga, I. (2011). Construyendo un lugar en la profesión: trayectorias de las arquitectas españolas. Feminismo/s, 17, 155-181. https://doi.org/10.14198/fem.2011.17.08

Arenas-Molina, M. T. (2014). El techo de cristal en el sector de la construcción en Andalucía. Universidad de Sevilla, España.

Barberá, E., Ramos, A., \& Candela, C. (2011). Laberinto de cristal en el liderazgo de las mujeres. Psicothema, 23(2), 173-179.

Barberá, E., Sarrió, M., \& Ramos, A. (2000). Mujeres directivas: promoción profesional en España y el Reino Unido (First Edit). Institut Universitari d’Estudis de la Dona, Universitat de València.

Burin, M. (2008). "Glass frontiers" in women's professional careers. Gender, subjectivity, globalization. Anuario de Psicologia, 39(1), 75-86.

Burin, M., \& Dio Bleichmar, E. (1996). Género, psicoanálisis, subjetividad. Buenos Aires, Argentina: Paidós. 
Eagly, A., \& Carli, L. (2007). Las mujeres y el laberinto del liderazgo. Harvard Business Review, 85(9), 76-85.

Estebaranz, A., Gallego, B., Ramírez, L., \& Rodríguez, A. (2004). Roles, valores y competencias de las mujeres que han roto el techo de cristal. Córdoba: Diputación de Córdoba.

European Commission. (2012). Communication from the Commission to the European Parliament and the Council. Strategy for the sustainable competitiveness of the construction sector and its enterprises. Retrieved from https://ec.europa.eu/transparency/regdoc/rep/1/2012/EN/12012-433-EN-F1-1.Pdf

European Commission. (2016). She Figures 2015: Gender in Research and Innovation. Brussels, Belgium: Directorate General for Research and Innovation. https://doi.org/10.2777/744106

European Construction Industry Federation. (2015). Key figures 2015-activity $2014 . \quad$ Retrieved November 30, 2015, from http://www.sefifrance.fr/images/documents/fiec_key_figures_edition_2016_final.pdf

Fernández-Palacín, F., López-Fernández, M., Maeztu-Herrera, I., \& Martín-Prius, A. (2010). El techo de cristal en las pequeñas y medianas empresas. Revista de Estudios Empresariales. Segunda Época, 1, 231-247.

Infante, M., Román, M., \& Traverso, J. (2012). El sector español de la construcción bajo la perspectiva de género: Análisis de las condiciones laborales. Revista de La Construcción, 11(1), 32-43. https://doi.org/10.4067/S0718-915X2012000100004

Instituto Andaluz de la Mujer. (2003). Estudio cualitativo de las mujeres andaluzas en el sector de la construcción. Sevilla, Spain: Instituto Andaluz de la Mujer.

Instituto de la Mujer. (2008). Experiencias y perspectivas de competitividad en empresas con presencia de mujeres en los consejos de administración. Madrid, Spain.: Instituto de la Mujer.

Martínez, M. I., Guilló, N., Santero, R., \& Castro, R. B. (2011). Trayectorias laborales de las mujeres que ocupan puestos de alta cualificación. Madrid, Spain.: Ministerio de Sanidad, Política Social e Igualdad.

Navarro-Astor, E., Infante-Perea, M., \& Román-Onsalo, M. (2016). Revisión internacional de estudios de barreras de carrera bajo la perspectiva de género en la industria de la construcción. Revista Innovar Journal Revista de Ciencias Administrativas Y Sociales, $26(61)$, 103. https://doi.org/10.15446/innovar.v26n61.57169

Núñez Domínguez, T., \& Estebaranz, A. (2014). Leadership and corporate citizenship : What can we learn from woman leaders in the Andalusian Companies. Journal for Educators, Teachers and Trainers, 5(3), 243-254.

Osca, A., \& López-Sáez, M. (1994). Desarrollo de carrera y género: Factores que influyen en las diferencias entre hombres y mujeres. Revista de Psicología Del Trabajo Y de Las Organizaciones, 10(28), 73-86.

Román-Onsalo, M., Infante-Perea, M., \& Traverso-Cortés, J. (2009). Segregación ocupacional y empleabilidad femenina en el sector andaluz de la construcción. In Actas del I Congreso Universitario Andaluz Investigación y Género (pp. 1191-1210). Sevilla, Spain.

Román Onsalo, M., Ríos Paniagua, A., \& Traverso Cortés, J. (2013). Barreras de género en el desarrollo profesional de mujeres técnicas de la Construcción. Revista de La Construcción, 12(1), 87-99. https://doi.org/10.4067/S0718-915X2013000100009

Schein, V. E. (1973). The relationship between sex role stereotypes and requisite management characteristics. Journal of Applied Psychology, 57(2), 95-100. https://doi.org/10.1037/h0037128

Simpson, R. (2000). Gender mix and organisational fit: how gender imbalance at different levels of the organisation impacts on women managers Women in Management Review, 15(1), 5-18. https://doi.org/10.1108/09649420010310173

Taylor, S., \& Bogdan, R. (1987). Summary for Policymakers. In Climate Change 2013 - The Physical Science Basis (pp. 1-30). Cambridge, UK: Cambridge University Press. https://doi.org/10.1017/CBO9781107415324.004

Torres Martos, M. J., \& Román-Onsalo, M. (2011). Análisis de la implantación de planes de gualdad en las empresas del sector andaluz de la construcción. In Logros y retos: Actas del III congreso universitario nacional "Investigación y género" (pp. 1940-1961). Sevilla, Spain.

Valles, M. (1997). Técnicas cualitativas de investigación social: Reflexión metodológica y práctica profesional (First Edit). Madrid, Spain: Síntesis.

Van Dijk, T. A. (2011). Discurso y poder. Barcelona, Spain: Gedisa. 